\title{
Is There Any Association Between Uric Acid to High-density Lipoprotein Cholesterol Ratio and Erectile Dysfunction?
}

\section{Ürik Asitin Yüksek Yoğunluklu Lipoprotein Kolesterole Oranı ile Erektil Disfonksiyon Arasında Bir İlişski Var mı?}

\author{
Dilay Karabulut $^{1}$ (D), Mustafa Gurkan Yenice $^{2}$ (D) \\ ${ }^{1}$ Department of Cardiology, University of Health Sciences, Dr. Sadi Konuk Training and Research Hospital, Istanbul, Turkey \\ ${ }^{2}$ Department of Urology, University of Health Sciences, Dr. Sadi Konuk Training and Research Hospital, Istanbul, Turkey
}

Cite as: Karabulut D, Yenice MG. Is there any association between uric acid to high-density lipoprotein cholesterol ratio and erectile dysfunction? Grand J Urol 2021;1(3):116-121.

Submission date: 11 July 2021

Acceptance date: 01 September 2021

Online first: 09 September 2021

Publication date: 20 September 2021

Corresponding Author: Dilay Karabulut / University of Health Sciences, Dr. Sadi Konuk Training and Research Hospital, Department of Cardiology, Istanbul, Turkey / dilay_karakozak@hotmail.com ORCID ID: 0000-0003-1896-0096

\begin{abstract}
Objective: Elevated uric acid (UA) and low levels of high-density lipoprotein (HDL) cholesterol are associated with cardiovascular events and mortality. Erectile dysfunction (ED) has been considered an early marker of cardiovascular disease (CVD). Therefore, this study aimed to investigate the uric acid/ HDL ratio (UHR) as a nowel marker in patients with ED.

Materials and Methods: The study included 147 patients with a mean age of 50 years (range 32-76 years). Retrospective analyses were performed on the patients who were admitted to urology outpatient clinics. The laboratory parameter results were retrieved from the hospital medical records, and the UHR value was calculated. Patients were categorized into three groups according to the International Index of Erectile Function (IIEF) score. UHR was compared between groups, and its predictive value was evaluated using regression analysis and ROC curve analysis.

Results: Age was found to be significantly different in all three groups (Groups 1-2, $\mathrm{p}=0.001$; Groups 1-3, $\mathrm{p}=0.000$; Groups 2-3, $\mathrm{p}=0.001$ ). It was observed that the degree of ED increased with age. The values of UA and HDL were similar in all groups ( $p>0.05$ ). In contrast, the UHR value was statistically significantly higher $0.15(0.083-0.288, \mathrm{p}=0.047)$ in the moderate-severe ED (Group 3). ROC curve analyses revealed that UHR predicted severe ED (IIEF 5-11) with 42.9\% sensitivity and $87.3 \%$ specificity (AUC:0.66, CI 95\% 0.538-0.781, p=0.019).

Conclusion: UHR may serve as a severe ED indicator in patients admitted to the cardiology outpatient clinic since it has a significant association with a low IIEF score.
\end{abstract}

Keywords: erectile dysfunction, uric acid, high-density lipoprotein, uric acid/ HDL ratio

$\ddot{\mathrm{O} z}$

Amaç: Yüksek ürik asit (UA) ve düşük yüksek yoğunluklu lipoprotein (HDL) kolesterol seviyeleri kardiyovasküler olaylar ve mortalite ile ilişkilidir. Erektil disfonksiyon (ED), kardiyovasküler hastalığın erken bir belirteci olarak kabul edilmiştir. Bu nedenle, bu çalışmada ED’li hastalarda bir yeni belirteç olarak ürik asit/HDL oranını (UHR) araştırmayı amaçladık.

Gereçler ve Yöntemler: Çalışmaya yaş ortalaması 50 (32-76 yaş aralığında) olan 147 hasta dahil edildi. Üroloji polikliniğine başvuran hastaların retrospektif analizleri yapıldı. Hastaların laboratuvar parametreleri hastane tıbbi kayıtlarından alındı ve UHR değerleri hesaplandı. Hastalar Uluslararası Erektil Fonksiyon İndeksi (IIEF) skoruna göre üç gruba ayrıldı. UHR gruplar arasında karşılaştırıldı; prediktif değeri regresyon analizi ve ROC eğrisi analizi ile değerlendirildi.

Bulgular: Her üç grupta da yaş anlamlı olarak farklı bulundu (Grup 1-2, p=0,001; Grup 1-3, p=0,000; Grup 2-3, p=0,001). ED derecesinin yaşla birlikte arttığ gözlendi. Ürik asit ve HDL değerleri üç grup arasında anlamlı farklılık göstermedi (p>0.05). Buna karşılık, orta-şiddetli ED’de (Grup 3) UHR değeri istatistiksel olarak anlamlı derecede yüksekti 0.15 (0.083-0.288, p=0.047). ROC eğrisi analizi, UHR'nin \% 42.9 duyarlılık ve \% 87.3 özgüllükle (AUC: 0.66, CI \%95 0.538-0.781, p=0.019) şiddetli ED’yi (IIEF 5-11) öngördüğünü ortaya koydu.

Sonuç: UHR, düşük IIEF skoru ile anlamlı bir ilişkisi olduğu için kardiyoloji polikliniğine başvuran hastalarda ciddi bir ED göstergesi olarak kullanılabilir.

Anahtar kelimeler: erektil disfonksiyon, ürik asit, yüksek yoğunluklu lipoprotein, ürik asit/HDL oranı

ORCID ID: M.G. Yenice 0000-0002-5813-3565

(C) Copyright 2021 by GJU. This journal is published by Logos Medical Publishing. This is an Open Access article distributed under the terms of the Creative Commons Attribution NonCommercial

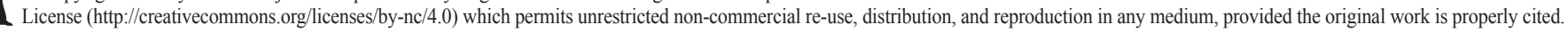




\section{Introduction}

Sexual health is one of the essential components of global health and good life of quality. Atherosclerotic cardiovascular disease (ASCVD) and vascular sexual dysfunction have similar pathogenesis [1]. Erectile dysfunction (ED) is defined as the inability of erection to last long enough to start and maintain sexual intercourse. About $1 / 4$ to $1 / 3$ of adult men experience this problem $[2,3]$. ED may develop due to many reasons such as genetic, organic, anatomical disorders, systemic diseases, lifestyle, and environmental factors. Usually, the underlying cause is not single but a combination of several factors [4].

Vascular damage due to endothelial dysfunction prevents adequate vasodilation of the penile vessels in response to sexual stimulation and causes ED. Therefore, vascular ED may be an early manifestation of CVD and is associated with vascular risk factors such as hipertension (HT), diabetes mellitus (DM), dyslipidemia and, smoking [5].

The enzyme xanthine oxidase synthesizes uric acid [6]. Uric acid (UA) to high-density lipoprotein (HDL)-cholesterol ratio (UHR) is a new parameter, which has been investigated in patients with type 2 diabetes mellitus with metabolic syndrome [7]. HDL cholesterol levels are negatively correlated with oxidative stress and the degree of inflammation in chronic diseases [8]. Several epidemiological studies showed significant relationship between serum UA levels and various cardiovascular conditions such as HT, metabolic syndrome, coronary artery disease (CAD), cerebrovascular (CV) disease, and dementia. [9-12].

Studies concluded that there is a significant relationship between uric acid and inflammation. It has been claimed that the effects of uric acid on mortality and poor prognosis occur through its pro-inflammatory mechanism [13]. High uric acid and low HDL lead to poor cardiovascular outcomes by increasing endothelial dysfunction and oxidative stress. Studies have shown that the combined effect of the two causes more damage [14,15]. The related literature shows that, there is limited knowledge about the relationship between UHR and ED. Considering the strong relationship between erectile dysfunction and cardiac diseases, it was hypothesized that the uric acid to HDL ratio, associated with cardiovascular mortality, could predict erectile dysfunction.

\section{Material and Method}

This single-center study was conducted on a total of 147 patients with a mean age of 50 years (range 32-76 years). Retrospective analyses were performed on the patients who have been admitted to urology outpatient clinics between 2015 and 2019. The detailed medical history of the study population was retrieved from the hospital medical records. Patients were categorized into three groups according to the IIEF score. Group 1 was formed of patients with an IIEF score of 22-25, without erectile dysfunction, Group 2 of patients with moderate-to-mild ED with an IIEF score of 12-24, and Group 3 of those with an IIEF score of 5-11 with moderate-to-severe ED.
Exclusion criteria were as follows; active malignant disease, systemic inflammatory or infectious disease, surgery or trauma within one month, end-stage renal failure (eGFR $<15$ $\mathrm{ml} / \mathrm{min} / 1.73 \mathrm{~m}^{2}$ ), liver failure, patients taking medications that may affect serum uric acid levels such as thiazides, furosemide, acetylsalicylic acid, etc. and medicines that may affect serum lipid levels such as statins, fibrates, niacin, etc., and that may affect erectile dysfunction such as beta-blockers, thiazide diuretics, and those with erectile dysfunction due to psychogenic and hormonal reasons.

Age, gender, smoking, and IIEF scores were recorded from the patient files and hospital medical records. Laboratory parameters, such as blood uric acid, total cholesterol, lowdensity lipoprotein cholesterol (LDL), high-density lipoprotein cholesterol (HDL), and triglyceride (TG), were measured using an automatic biochemical analyzer (Architect C8000, USA), and results were obtained from the same database and patient files. The uric acid to HDL ratio (UHR) is calculated by dividing serum uric acid level by HDL cholesterol.

Hypertension was accepted as systolic blood pressure (BP) of $\geq 140 \mathrm{mmHg}$ or diastolic BP of $\geq 90 \mathrm{mmHg}$ or both or the use of antihypertensive drugs. DM was defined as the use of antidiabetic medications or fasting plasma glucose levels $\geq 126 \mathrm{mg} /$ $\mathrm{dL}$ in at least two measurements or a glycated hemoglobin ratio (HbAlc) of $\geq 6.5 \%$. The study was approved by the Institutional Review Board Ethics Committee of Dr. Sadi Konuk Training and Research Hospital (Approval no: 2021/342). Written informed consent was obtained from all patients.

\section{Evaluation of Erectile Function}

ED was evaluated by the Turkish version of the International Index of Erectile Function with five questions (IIEF-5) [16]. This is a self-administered questionnaire in which patient responses are based on their experience during the last four weeks and are scored on a 5-point Likert scale, with lower values representing the poorer sexual function. Total scores are classified as; 2225: No erectile dysfunction; 17-21: Mild erectile dysfunction; 12-16: Mild to moderate erectile dysfunction; 8-11: Moderate erectile dysfunction; and 5-7: Severe erectile dysfunction [17]. This questionnaire has been shown to provide data on ED 98\% sensitivity and $88 \%$ specificity [18].

\section{Statistically Analysis}

All statistical calculations were made using IBM SPSS statistics vn.25 software. The normality of data distribution was assessed with the Shapiro-Wilk test. Skewed data were expressed as median and minimum-maximum values. Since the data were not normally distributed, the Kruskal-Wallis test was used to compare the groups. ROC curve analysis was used to assess the predictive ability of UHR for ED. Univariate and Multivariate Logistic regression analyses were performed to investigate predictors of ED. 


\section{Results}

The demographic and clinical data of patients are summarized in Table 1. Age was found to be significantly different in all three groups (Groups 1-2, $\mathrm{p}=0.001$; Groups 1-3, $\mathrm{p}=0.000$; Groups 2-3, $\mathrm{p}=0.001)$. The degree of ED was observed to increase with age. A statistically significant difference was determined between the three groups in respect of total cholesterol values. Post hoc analyses showed that this difference was between Group 1 (normal patients with IIEF 22-25) and Group 2 (patients with moderate-mild IIEF 12-21) ( $\mathrm{p}=0.036)$. DM was observed at a higher rate in Group 3. No significant difference was determined between the groups in respect of triglyceride, LDL cholesterol, HDL cholesterol, and UA values ( $p>0.05$ for all).

The laboratory data of the study groups are summarized in Table 2. The values of uric acid and HDL were similar in all groups $(p>0.05)$. The UHR value was determined to be statistically significantly higher $0.15(0.083-0.288, \mathrm{p}=0.047)$ in Group 3 (moderate-severe ED).

Multiple logistic regression analysis was also performed to define the predictive value of variables for the presence of ED. UHR was not found to be an independent predictor of $\mathrm{ED}[\mathrm{p}=0.216,95 \%$ CI for OR:748.11, (0.021-2664.8)], but age predicted ED [p=0.002, 95\% CI for OR:1.130 (1.044-1.233)] (Table 3).

ROC curve analyses revealed that UHR predicted severe ED (IIEF 5-11) with $42.9 \%$ sensitivity and $87.3 \%$ specificity (AUC:0.66, CI $95 \% 0.538-0.781, \mathrm{p}=0.019$ ) (Figure 1).

\section{Discussion}

The principal finding of the present study was that UHR was statistically significantly higher in patients with moderatesevere ED than in those with mild and mild to moderate ED. Also, UHD predicted severe ED.

Table 1. Clinical characteristics of the study population

\begin{tabular}{l|l|l}
\hline & Mean \pm SD & Median (min-max) \\
\hline Age & $49.93 \pm 9.24$ & $50.00(32-76)$ \\
\hline Smoking (n) & 62 & 42.2 \\
\hline Diabetes Mellitus (n) & 39 & 24.5 \\
\hline Hypertension (n) & 61 & 41.5 \\
\hline IIEF -5 & $16.90 \pm 4.758$ & $18.00(5-25)$ \\
\hline Triglyceride (mg/dl) & $159.80 \pm 83.373$ & $136.00(32-422)$ \\
\hline HDL-C (mg/dl) & $45.25 \pm 13.841$ & $42.00(25-136)$ \\
\hline LDL-C (mg/dl) & $123.98 \pm 37.407$ & $127.80(41-230)$ \\
\hline TC (mg/dl) & $198.85 \pm 42.621$ & $205.00(96-314)$ \\
\hline Uric acid (mg/dl) & $5.61 \pm 1.184$ & $5.60(3-13)$ \\
\hline UHR (\%) & $0.13 \pm 0.049$ & $0.12(0.033-0.288)$ \\
\hline
\end{tabular}

IIEF: international index of erectile function; HDL-C: high-density lipoprotein cholesterol; LDL-C: low-density lipoprotein cholesterol; TC: total cholesterol; UHR: uric acid to hdl-cholesterol ratio

Table 2. Clinical characteristics and laboratory parameters of the study groups

\begin{tabular}{l|l|l|l|l}
\hline & Group 1 (n=24) & Group 2 (n=102) & Group 3 (n=21) & P- value \\
\hline Age & $41.00(32-57)$ & $50.00(33-75)$ & $58.00(43-76)$ & 0.000 \\
\hline Smoking (n, \%) & $16(66.7)$ & $39(39.0)$ & $7(33.3)$ & 0.031 \\
\hline Hypertension (n, \%) & $3(12.5)$ & $41(41.0)$ & $17(27.9)$ & 0.000 \\
\hline Diabetes Mellitus (n, \%) & $2(8.3)$ & $21(21.0)$ & $13(61.9)$ & 0.000 \\
\hline TG (mg/dl) & $140.00(58-386)$ & $131.50(32-422)$ & $141.00(64-350)$ & 0.841 \\
\hline HDL-C (mg/d) & $42.50(32-136)$ & $42.55(25-113)$ & $40.00(28-50)$ & 0.092 \\
\hline LDL-C (mg/dl) & $102.00(30-188)$ & $130.60(41-230)$ & $120.20(64-188)$ & 0.103 \\
\hline TC (mg/dl) & $170.50(108-252)$ & $211.00(96-314)$ & $196.00(119-253)$ & 0.029 \\
\hline UA (mg/dl) & $5.30(3-9)$ & $5.60(3-9)$ & $6.12(4-13)$ & 0.599 \\
\hline UHR (\%) & $0.11(0.033-0.201)$ & $0.12(0.347-0.270)$ & $0.15(0.083-0.288)$ & 0.047 \\
\hline
\end{tabular}

TG: triglyceride; HDL-C: high-density lipoprotein cholesterol; LDL-C: low-density lipoprotein cholesterol; TC: total cholesterol; UA: uric acid; UHR: uric acid to HDL-cholesterol ratio 
Table 3. Univariate and multivariate logistics regression analysis for independent predictors of erectile dysfunction

\begin{tabular}{l|c|c|c|c}
\hline & \multicolumn{2}{|c|}{ Univariate } & \multicolumn{2}{c}{ Multivariate } \\
\hline Parameter & Odds Ratio (95\% CI) & P-value & Odds Ratio (95\% CI) & P-value \\
\hline Age & $1.157(1.074-1.247)$ & 0.000 & $1.130(1.044-1.233)$ & 0.002 \\
\hline Smoking & $0.307(0.122-0.773)$ & 0.012 & $0.456(0.166-1.253)$ & 0.128 \\
\hline HT & $6.444(1.826-22.747)$ & 0.004 & $3.171(0.826-12.172)$ & 0.093 \\
\hline UHR & $63.42(0.039-1042.8)$ & 0.193 & $748.11(0.021-2664.8)$ & 0.216 \\
\hline
\end{tabular}

HT: hypertension; UHR: uric acid to HDL-cholesterol ratio

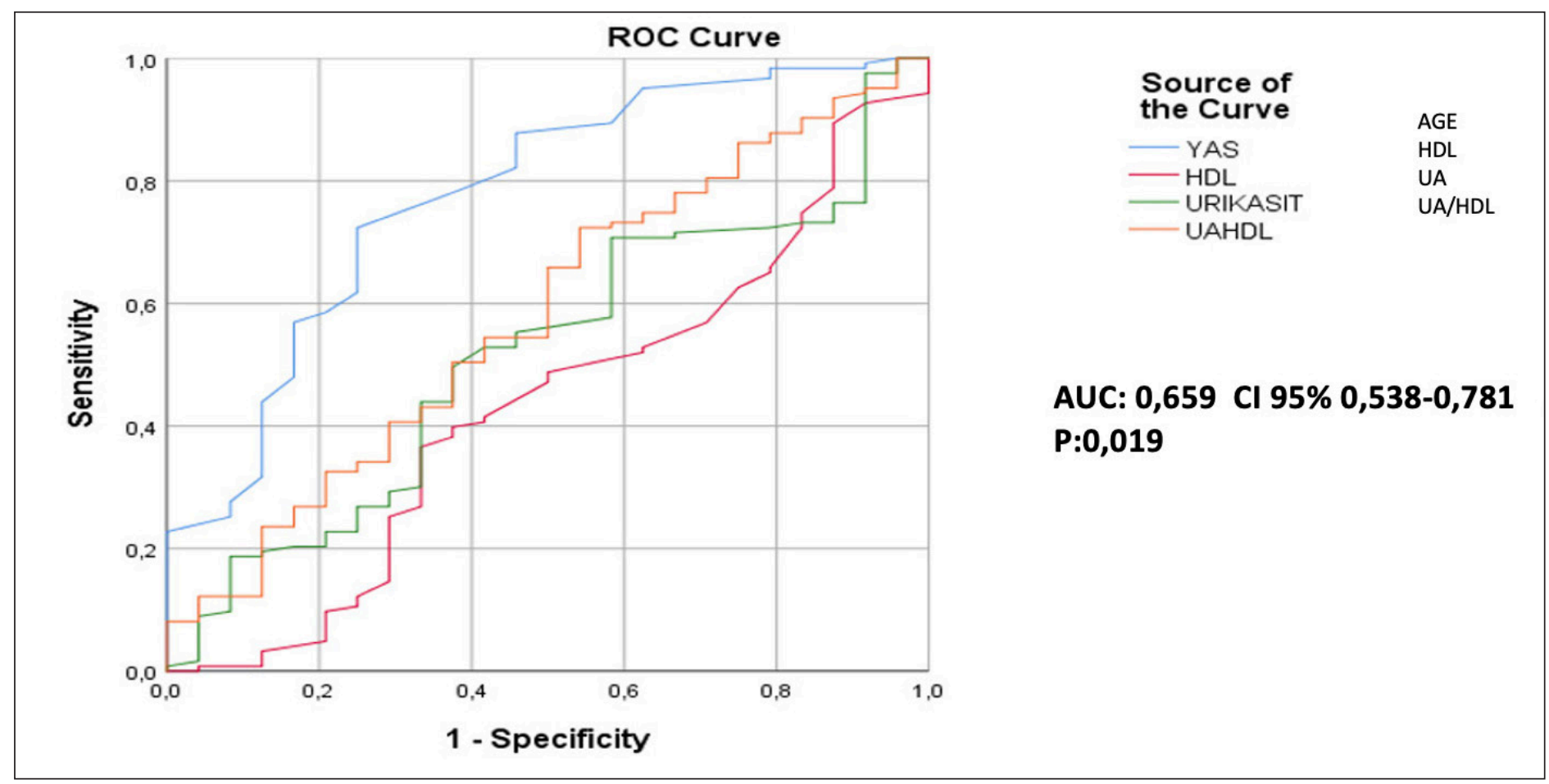

Figure 1. ROC curve of the study parameters in predicting severe ED

Multiple mechanisms such as androgen hormone levels, psychosocial factors, vascular damage, and endothelial dysfunction play a key role in the pathogenesis of ED. It is thought that uric acid may be associated with ED since it affects endothelial and vascular functions $[19,20]$.

Meta-analyses have shown that UA is also a predictor of cardiovascular risk factors such as insulin resistance, HT and the development of renal disease (20-23). Therefore, all these risk factors that cause endothelial and vascular damage are also associated with ED.

UHR is a new marker consisting of two values, namely UA and HDL cholesterol. Using UHR, the degree of inflammation and endothelial dysfunction can be determined which may be involved in ED, indicated by a higher level of UA or a lower level of HDL cholesterol, or both. In a recent study, UHR was reported to be a predictor of metabolic syndrome in type $2 \mathrm{DM}$ patients and was suggested as a marker of high sensitivity and specificity for the control of diabetes. Another study by Ruihua Liu et al. showed a significant association of UHR with cardiovascular mortality in peritoneal dialysis patients with age $>65$ years, malnutrition, DM, and CVD history [24].

ED may be an early predictor of CVD; thus, it may provide insight for clinicians in investigating risk factors. It was thought that the patients admitted to the cardiology department were reluctant to express complaints of ED. Therefore, it may be important to refer patients with high UHR to urology outpatient clinics for early diagnosis of ED. Thus, early detection of highrisk patients for ED and an early start to treatment will increase their quality of life, and most importantly, reduce the risk of CVD. Thus, early diagnosis of ED can accelerate the diagnosis and treatment of underlying risk factors and prevent major adverse cardiocerebrovascular events [5]. Our study is the first to examine the relationship between uric acid/HDL ratio and erectile dysfunction to the best of our knowledge.

Limitations of the study: The cross-sectional and retrospective design of the study and the limited number of patients can be considered limitations of this study. 


\section{Conclusion}

UHR may serve as an indicator of severe ED in patients admitted to the cardiology outpatient clinic since it has a significant association with a low IIEF score. More comprehensive prospective cohort studies may yield different results and show that UHR may be a predictor of ED.

Ethics Committee Approval: The study was approved by the Institutional Review Board Ethics Committee of Dr. Sadi Konuk Training and Research Hospital, Istanbul, Turkey (Approval date, and registration number: 02.08.2021/342)

Informed Consent: An informed consent was obtained from all the patients.

Publication: The results of the study were not published in full or in part in form of abstracts.

Peer-review: Externally peer-reviewed.

Authorship Contributions: Any contribution was not made by any individual not listed as an author. Concept - D.K., M.G.Y.; Design - D.K., M.G.Y.; Supervision - D.K., M.G.Y.; Resources - D.K., M.G.Y.; Materials - D.K., M.G.Y.; Data Collection and/ orProcessing - D.K., M.G.Y.; Analysis and/or Interpretation - D.K., M.G.Y.; Literature Search - D.K., M.G.Y.; Writing D.K., M.G.Y.; Critical Review - D.K., M.G.Y.

Conflict of Interests: The authors have no conflict of interests to declare.

Financial Disclosure: The authors declare that this study received no financial support.

\section{References}

[1] Viigimaa M, Vlachopoulos C, Doumas M, Wolf J, Imprialos K, Terentes-Printzios D, et al. Update of the position paper on arterial hypertension and erectile dysfunction. J Hypertens 2020;38:1220-34.

https://doi.org/10.1097/HJH.0000000000002382.

[2] Selvin E, Burnett AL, Platz EA. Prevalence and risk factors for erectile dysfunction in the US. Am J Med 2007;120:151-7. https://doi.org/10.1016/j.amjmed.2006.06.010.

[3] Shaeer O, Shaeer K. The Global Online Sexuality Survey (GOSS): the United States of American in 2011. Chapter I: erectile dysfunction among English-speakers. J Sex Med 2012;9:3018-27. https://doi.org/10.1111/j.1743-6109.2012.02976.x.

[4] Heaton JPW, Adams MA. Causes of erectile dysfunction. Endocrine 2004;23:119-23. https://doi.org/10.1385/ENDO:23:2-3:119.

[5] Jackson G. Prevention of cardiovascular disease by the early identification of erectile dysfunction. Int J Impot Res 2008;20Supp12:S9-14.

https://doi.org/10.1038/ijir.2008.47.
[6] Nejatinamini S, Ataie-Jafari A, Qorbani M, Nikoohemat S, Kelishadi R, Asayesh H, et al. Association between serum uric acid level and metabolic syndrome components. J Diabetes Metab Disord 2015;14:1-7. https://doi.org/10.1186/s40200-015-0200-z.

[7] Kocak MZ, Aktas G, Erkus E, Sincer I, Atak B, Duman T. Serum uric acid to HDL-cholesterol ratio is a strong predictor of metabolic syndrome in type 2 diabetes mellitus. Rev Assoc Med Bras 2019;65:9-15.

https://doi.org/10.1590/1806-9282.65.1.9.

[8] Ingelsson E, Schaefer EJ, Contois JH, McNamara JR, Sullivan L, Keyes MJ, et al. Clinical utility of different lipid measures for prediction of coronary heart disease in men and women. JAMA 2007;298:776-85. https://doi.org/10.1001/jama.298.7.776.

[9] Kuwabara M, Hisatome I, Niwa K, Hara S, Roncal-Jimenez $\mathrm{CA}$, Bjornstad $\mathrm{P}$, et al. Uric acid is a strong risk marker for developing hypertension from prehypertension: a 5-year Japanese cohort study. Hypertension 2018;71:78-86. https://doi.org/10.1161/HYPERTENSIONAHA.117.10370.

[10] Yu TY, Jee JH, Bae JC, Jin SM1, Baek JH, Lee MK, et al. Serum uric acid: a strong and independent predictor of metabolic syndrome after adjusting for body composition. Metabolism 2016;65:432-40. https://doi.org/10.1016/j.metabol.2015.11.003.

[11] Biscaglia S, Ceconi C, Malagù M, Pavasini R, Ferrari R. Uric acid and coronary artery disease: an elusive link deserving further attention. Int J Cardiol 2016;213:28-32. https://doi.org/10.1016/j.ijcard.2015.08.086.

[12] Zhang X, Huang ZC, Lu TS, You SJ, Cao YJ, Liu CF. Prognostic significance of uric acid levels in ischemic stroke patients. Neurotox Res 2016;29:10-20. https://doi.org/10.1007/s12640-015-9561-9.

[13] Sezgin N, Barutcu I, Sezgin AT, Gullu H, Turkmen M, Esen $\mathrm{AM}$, et al. Plasma nitric oxide level and its role in slow coronary flow phenomenon. Int Heart J 2005;46:373-82. https://doi.org/10.1536/ihj.46.373.

[14] Ko J, Kang HJ, Kim DA, Kim MJ, Ryu ES, Lee S, et al. Uric acid-induced the phenotype transition of vascular endothelial cells via induction of oxidative stress and glycocalyx shedding. FASEB J 2019;33:13334-45. https://doi.org/10.1096/fj.201901148R.

[15] Nagao M, Nakajima H, Toh R, Hirata KI, Ishida T. Cardioprotective effects of high-density lipoprotein beyond its anti-atherogenic action. J Atheroscler Thromb 2018;25:985-93. https://doi.org/10.5551/jat.RV17025.

[16] Turunç T, Deveci S, Güvel S, Peşkircioğlu L. The assessment of Turkish validation with 5 question version of the international index of erectile function (IIEF-5). Turk J Urol 2007;33:45-9.

https://turkishjournalofurology.com/EN. 
[17] Rosen RC, Cappelleri JC, Smith MD, Lipsky J, Peña BM. Development and evaluation of an abridged, 5-item version of the International Index of Erectile Function (IIEF-5) as a diagnostic tool for erectile dysfunction. Int $\mathrm{J}$ Impot Res 1999;11:319-26.

https://doi.org/10.1038/sj.ijir.3900472.

[18] Rosen RC, Riley A, Wagner G, Osterloh IH, Kirkpatrick $\mathrm{J}$, Mishra A. The international index of erectile function (IIEF): a multidimensional scale for assessment of erectile dysfunction. Urology 1997;49:822-830.

https://doi.org/10.1016/s0090-4295(97)00238-0.

[19] Kanbay M, Sanchez-Lozada LG, Franco M, Madero M, Solak Y, Rodriguez-Iturbe B, et al. Microvascular disease and its role in the brain and cardiovascular system: a potential role for uric acid as a cardiorenal toxin. Nephrol Dial Transplant 2011;26:430-7. https://doi.org/10.1093/ndt/gfq635.

[20] Grayson PC, Kim SY, LaValley M, Choi HK. Hyperuricemia and incident hypertension: a systematic review and meta-analysis. Arthritis Care Res (Hoboken) 2011;63:102-10.

https://doi.org/10.1002/acr.20344.
[21] Kodama S, Saito K, Yachi Y, Asumi M, Sugawara A, Totsuka K, et al. Association between serum uric acid and development of type 2 diabetes. Diabetes Care 2009;32:1737-42.

https://doi.org/10.2337/dc09-0288.

[22] Feig DI. Uric acid a novel mediator and marker of risk in chronic kidney disease? Curr Opin Nephrol Hypertens 2009;18:526-30.

https://doi.org/10.1097/MNH.0b013e328330d9d0.

[23] Kanbay M, Ozkara A, Selcoki Y, Isik B, Turgut F, Bavbek $\mathrm{N}$, et al. Effect of treatment of hyperuricemia with allopurinol on blood pressure, creatinine clearance, and proteinuria in patients with normal renal functions. Int Urol Nephrol 2007;39:1227-33. https://doi.org/10.1007/s11255-007-9253-3.

[24] Liu R, Peng Y, Wu H, Diao X, Ye H, Huang X, et al. Uric acid to high-density lipoprotein cholesterol ratio predicts cardiovascular mortality in patients on peritoneal dialysis. Nutr Metab Cardiovasc Dis 2021;31:561-69. https://doi.org/10.1016/j.numecd.2020.10.005. 